\title{
ANALISIS PENGENDALIAN KUALITAS PRODUK BUCKET TIPE ZX 200 GP DENGAN METODE STATISTICAL PROCESS CONTROL DAN FAILURE MODE AND EFFECT ANALYSIS (STUDI KASUS: PT. CDE)
}

\author{
Wilson Kosasih, Adianto dan Erickson \\ Program Studi Teknik Industri Universitas Tarumanagara \\ e-mail: wilsonk@ft.untar.ac.id, ericsson_803@yahoo.com
}

\begin{abstract}
Abstrak
PT. CDE merupakan suatu perusahaan yang bergerak di bidang industri manufaktur alat berat. Salah satu produk yang dihasilkan oleh PT. CDE adalah bucket tipe ZX 200 GP. Berdasarkan data produksi yang diperoleh dari bulan Mei 2013 hingga September 2013, jenis kegagalan produk yang paling banyak ditemui adalah jenis cacat undercut. Dalam penelitian ini, pengendalian kualitas dilakukan dan dianalisis dengan menggunakan metode Statistical Process Control dan Failiure Mode and Effect Analysis (FMEA). Jenis FMEA yang digunakan adalah FMEA proses. Hasil analisis mengidentifikasi beberapa akar permasalahan utama yang menjadi penyebab munculnya kegagalan pada jenis cacat undercut yaitu: penyetelan mesin yang kurang tepat, kotornya ujung mata las, penggunaan mesin secara terus menerus, pemakaian kawat terlalu sedikit, kurang pemeriksaan kualitas, kemiringan elektroda yang kurang tepat, kecepatan pengelasan terlalu tinggi, kurang pengawasan kerja, dan pekerja yang kurang terampil. Maka daripada itu, dalam makalah ini diusulkan beberapa tindakan perbaikan kepada pihak manajemen untuk mengurangi kecacatan undercut yang terjadi, antara lain: mempekerjakan welder yang telah bersertifikasi, mengurangi kecepatan pengelasan sesuai dengan ketebalan material, melakukan pengarahan mengenai kemiringan elektroda yang sesuai dengan posisi pengelasan, mengatur besar arus dan tegangan pengelasan sesuai dengan tebal bahan dan diameter kawat elektroda, melakukan pemeriksaan kualitas secara rutin dan segera melakukan tindakan perbaikan bila terjadi kegagalan saat produksi.
\end{abstract}

Kata kunci: Pengendalian Kualitas, Statistical Process Control, Failure Mode and Effect Analysis

\begin{abstract}
PT. CDE is a company engaged in the manufacturing of heavy equipment. One of the products is produced by PT. CDE is a bucket with type ZX 200 GP. Based on production data were acquired from May 2013 to September 2013, the most frequently defect is undercut. In this study, the quality control was done and analyzed using Statistical Process Control and Failure Mode and Effect Analysis (FMEA). FMEA type used is FMEA process. There are some root of causes on the defect of undercut namely: Improper machine setup, dirty tip of the welding tool, high machine utilization, the use of wire too few, lacking the quality inspection, the slope of the electrode is less precise, welding speed is too high, lack of supervision of work, and less skilled workers. Hence, this paper proposed some corrective actions to management to reduce defect of undercut that occurs, among other things: employ a welder who has been certified, reduce the welding speed according to the thickness of the material, conduct training/briefing on the slope of the electrode according to the welding position, adjust the current and voltage welding according to the thickness of material and diameter of the wire electrode, perform quality checks regularly and promptly take action or improvement if a failure occurs during the production process
\end{abstract}

Keywords: Quality Control, Statistical Process Control, Failure Mode and Effect Analysis

\section{PENDAHULUAN}

PT. CDE merupakan suatu perusahaan yang bergerak di bidang industri manufaktur alat berat. Salah satu produk yang dihasilkan oleh perusahaan tersebut adalah bucket tipe ZX 200 GP. Untuk menjamin mutu produkyang dihasilkan, perusahaan memiliki acuan khusus yaitu berdasarkan standar American Welding
Society (AWS). Salah satu kendala yang masih dihadapi perusahaan adalah kualitas pengelasan yang kurang baik, sehingga menyebabkan timbulnya cacat pada hasil produk bucket tersebut.

Tujuan penelitian ini adalah mengetahui faktor-faktor yang mempengaruhi terjadinya cacat pada produk bucket, mengidentifikasi 
jenis cacat potensial yang terjadi pada bucket, dan mengidentifikasi efek yang timbul akibat dari cacat produk. Manfaat dari penelitian ini adalah sebagai bahan pertimbangan bagi perusahaan dalam meningkatkan kualitas produknya.

\section{TINJAUAN PUSTAKA}

Pengendalian mutu statistik berkaitan dengan upaya menjamin kualitas dengan memperbaiki kualitas proses dan upaya menyelesaikan segala permasalahan selama proses [1,2]. Penelitian dilakukan dengan menggunakan statistical process control chart untuk data atribut yaitu peta kendali-p. Penentuan batas kendali dalam peta kendali-p adalah sebagai berikut $[1,2]$ :

$$
\begin{aligned}
& C L p=\frac{\sum_{i}^{n} \text { produk cacat }}{\sum_{i}^{n} \text { jumlah sampel }} \\
& U C L=C L p+3 \sqrt{\frac{C L p(1-C L p)}{n}} \\
& L C L=C L p-3 \sqrt{\frac{C L p(1-C L p)}{n}}
\end{aligned}
$$

dimana,

$$
\begin{aligned}
C L p: & (\text { Center Line p) = rata-rata bagian } \\
& \text { cacat keseluruhan } \\
U C L: & (\text { Upper Control Limit) }=\text { batas } \\
& \text { kendali atas } \\
L C L: & (\text { Lower Control Limit })=\text { batas } \\
& \text { kendali bawah } \\
n \quad: & \text { banyaknya pengamatan atau jumlah } \\
& \text { subgrup }
\end{aligned}
$$

Metode analisis yang digunakan dalam penelitian ini adalah Process Failure Mode and Effect Analysis (FMEA) dimana merupakan salah satu teknik sistematis untuk menganalisis kegagalan proses yang sering ataupun berpotensi terjadi. FMEA proses mengidentifikasi beberapa kesalahan potensial yang terjadi selama proses produksi yang dapat disebabkan oleh mesin, manusia, material, metode, maupun lingkungan kerja. Beberapa langkah dalam melakukan FMEA proses antara lain [4]:

a. Menentukan label pada masing-masing proses atau sistem b. Membuat penjelasan mengenai fungsi proses

c. Mengidentifikasi jenis cacat yang terjadi

d. Mengidentifikasi akibat dari cacat yang terjadi

e. Menentukan nilai severity

Nilai tingkat keparahan terdiri dari rating 1-10, semakin parah akibat yang ditimbulkan, maka semakin tinggi nilai rating yang diberikan.

f. Mengidentifikasi penyebab cacat

g. Menentukan nilai occurrence

Nilai tingkat kemungkinan diberikan untuk setiap penyebab cacat dan juga memiliki nilai rating dari 1-10. Semakin sering terjadi cacat, maka semakin tinggi nilai rating yang diberikan.

h. Mengidentifikasi kontrol yang dilakukan

i. Menentukan nilai detection

Nilai detection terdiri dari rating 1-10. Semakin sulit penyebab cacat dideteksi, maka semakin tinggi nilai rating yang diberikan.

j. $\quad$ Menghitung Risk Priority Number (RPN)

yang dinyatakan dengan persamaan:

$\mathrm{RPN}=$ severity $\mathrm{x}$ occurrence $\mathrm{x}$ detection

\section{METODOLOGI PENELITIAN}

Metodologi penelitian merupakan langkah awal yang harus ditetapkan dalam penelitian untuk membantu menyelesaikan pemecahan masalah yang ada. Diagram alir metodologi penelitian dapat dilihat pada Gambar 1.

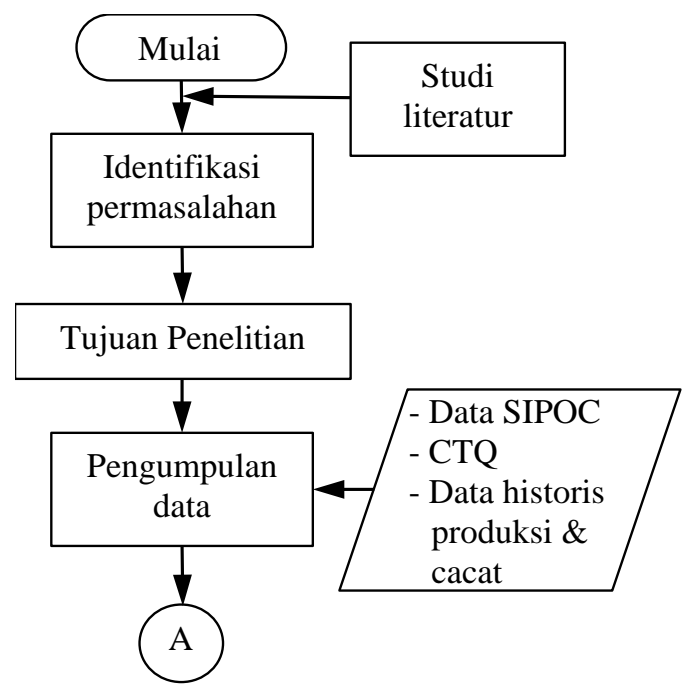

Gambar 1. Metodologi Penelitian 


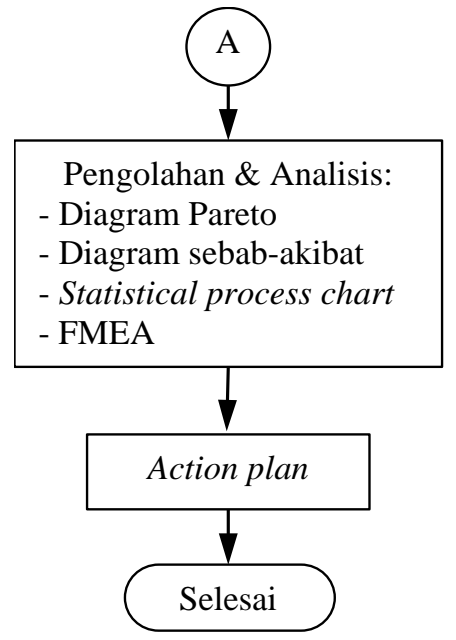

Lanjutan Gambar 1. Metodologi Penelitian

\section{HASIL DAN PEMBAHASAN}

Pengumpulan data pada penelitian ini dilakukan dengan wawancara langsung kepada pihak-pihak terkait maupun melakukan studi lapangan. Data yang dikumpulkan berupa data historis perusahaan meliputi data SIPOC, identifikasi Critical to Quality (CTQ), data produksi bucket, dan data cacat produksi.

\section{Diagram Supplier-Input-Process-Output- Customer (SIPOC) \\ Diagram SIPOC menyajikan tampilan} sekilas dari aliran kerja yang sesuai prosedur perusahaan, seperti ditunjukkan pada Gambar 2.

\section{Critical To Quality (CTQ)}

Critical To Quality (CTQ) untuk produk bucket dilihat dari segi material, proses, dan pengiriman. Critical To Quality dapat dilihat pada Gambar 3.

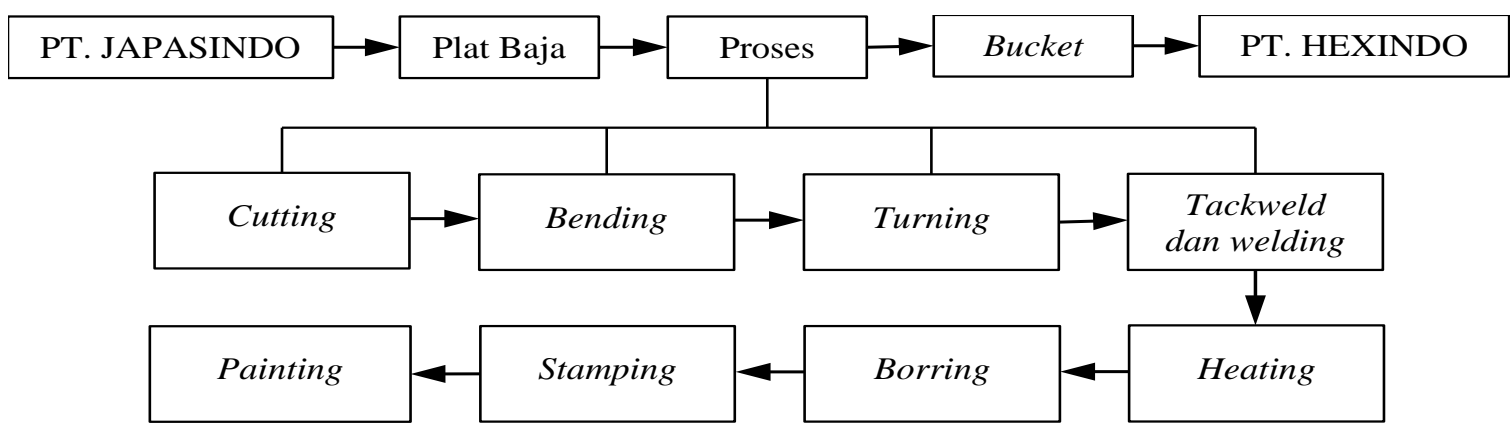

Gambar 2. Diagram SIPOC

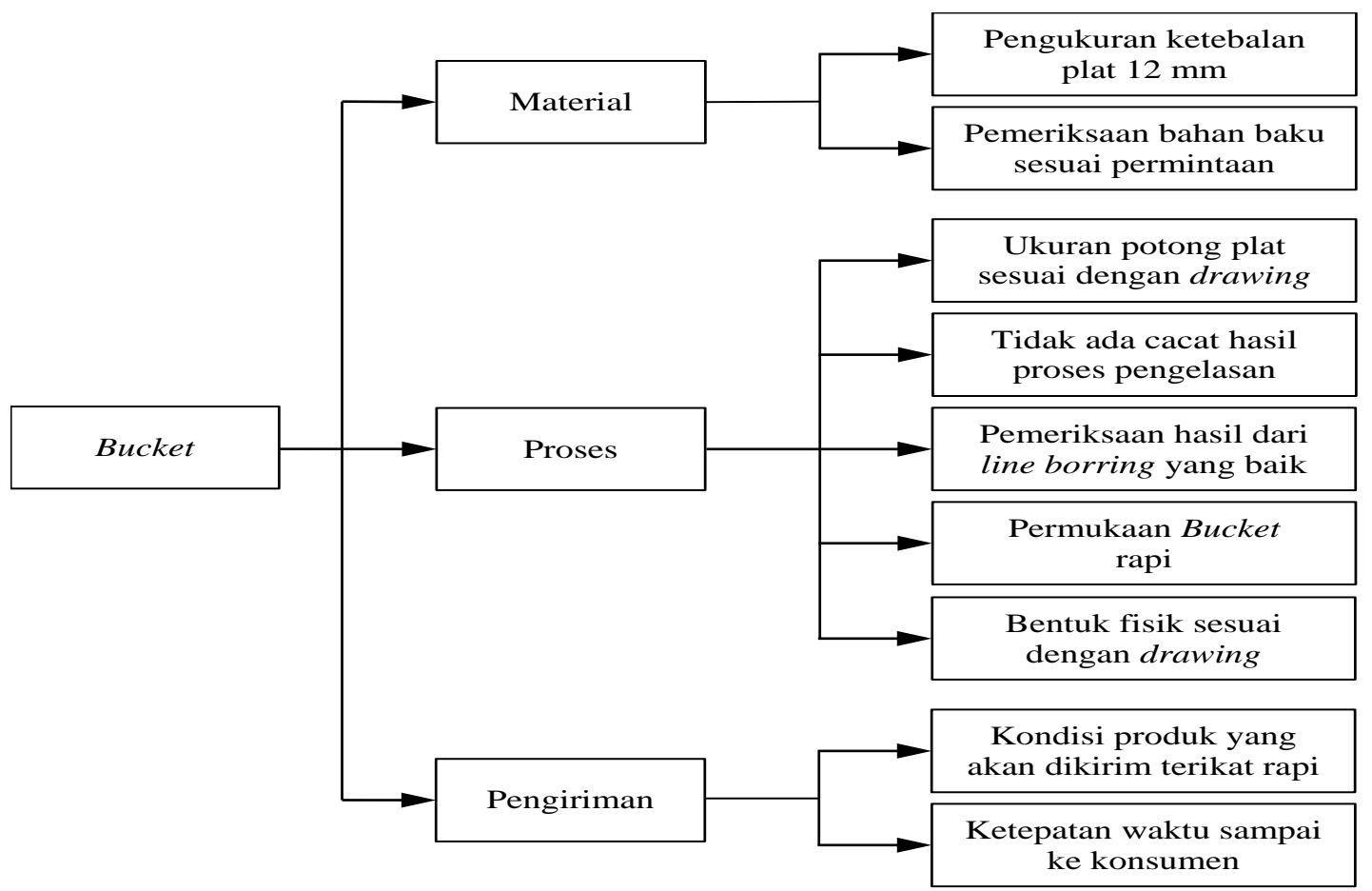

Gambar 3. Critical To Quality pada Bucket 


\section{Data Proses Produksi Bucket Tipe ZX 200 GP}

Dalam proses produksi Bucket Tipe ZX 200 GP tidak lepas dari defect atau cacat. Berikut ini adalah data jumlah produksi dan jumlah cacat yang terjadi di PT. CDE dari bulan Mei 2013 sampai dengan September 2013, seperti terlihat pada Tabel 1 .

\section{Peta Kendali P}

Peta kendali digunakan untuk menentukan proses produksi tersebut apakah berada dalam batas kendali atau di luar batas kendali. Gambar 4 merupakan peta kendali-p untuk hasil perhitungan dari bulan Mei 2013 sampai dengan September 2013. Dari peta kendali tersebut terlihat bahwa proses produksi bucket dari bulan Mei 2013 hingga September 2013 seluruhnya berada di dalam batas kendali, baik batas kendali bawah (low control limit - LCL) dan batas kendali atas (upper control limit UCL).

Tabel 1. Data Cacat Produk pada Bulan Mei 2013-September 2013

\begin{tabular}{rrrrrrrr}
\hline \multirow{2}{*}{ No } & \multirow{2}{*}{ Tanggal } & Produksi & \multicolumn{3}{c}{ Jenis Cacat pada Top Box Joint to Hook Up } & Total \\
\cline { 4 - 6 } & & Overlap & Undercut & Weaviness & Porosity & Cacat \\
\hline 1 & 10-Mei-13 & 4 & 2 & 1 & 0 & 0 & 3 \\
2 & 11-Mei-13 & 3 & 1 & 1 & 0 & 0 & 2 \\
3 & 30-Mei-13 & 2 & 0 & 0 & 1 & 0 & 1 \\
4 & 11-Jun-13 & 2 & 0 & 0 & 0 & 1 & 1 \\
5 & 12-Jun-13 & 2 & 0 & 1 & 0 & 0 & 1 \\
6 & 14-Jun-13 & 2 & 0 & 0 & 0 & 1 & 1 \\
7 & 15-Jun-13 & 1 & 0 & 0 & 0 & 0 & 0 \\
8 & 18-Jun-13 & 2 & 0 & 1 & 0 & 0 & 1 \\
9 & 19-Jun-13 & 3 & 1 & 1 & 0 & 0 & 2 \\
10 & 28-Jun-13 & 1 & 0 & 0 & 0 & 0 & 0 \\
11 & 20-Jul-13 & 2 & 0 & 0 & 0 & 0 & 0 \\
12 & 22-Jul-13 & 1 & 0 & 0 & 0 & 0 & 0 \\
13 & 26-Jul-13 & 2 & 1 & 0 & 0 & 0 & 1 \\
14 & 2-Aug-13 & 2 & 0 & 0 & 0 & 1 & 1 \\
15 & 3-Aug-13 & 2 & 0 & 0 & 0 & 1 & 1 \\
16 & 4-Aug-13 & 1 & 0 & 0 & 0 & 0 & 0 \\
17 & 8-Aug-13 & 1 & 0 & 0 & 0 & 0 & 0 \\
18 & 15-Aug-13 & 1 & 0 & 0 & 0 & 0 & 0 \\
19 & 26-Aug-13 & 5 & 1 & 1 & 0 & 0 & 2 \\
20 & 29-Aug-13 & 2 & 1 & 0 & 0 & 0 & 1 \\
21 & 30-Aug-13 & 2 & 0 & 1 & 0 & 0 & 1 \\
22 & 6-Sep-13 & 7 & 1 & 2 & 0 & 0 & 3 \\
23 & 15-Sep-13 & 2 & 0 & 1 & 0 & 0 & 1 \\
24 & 16-Sep-13 & 2 & 0 & 0 & 0 & 0 & 0 \\
25 & 20-Sep-13 & 2 & 0 & 1 & 0 & 0 & 1 \\
\hline
\end{tabular}

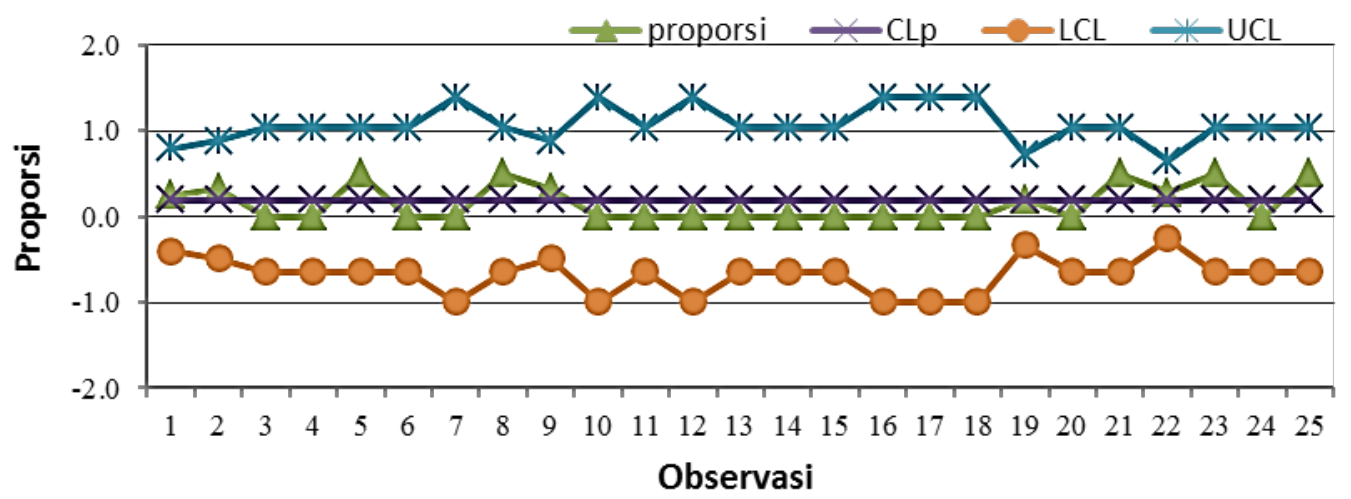

Gambar 4. Peta Kendali P 


\section{Pareto Chart for Defects}

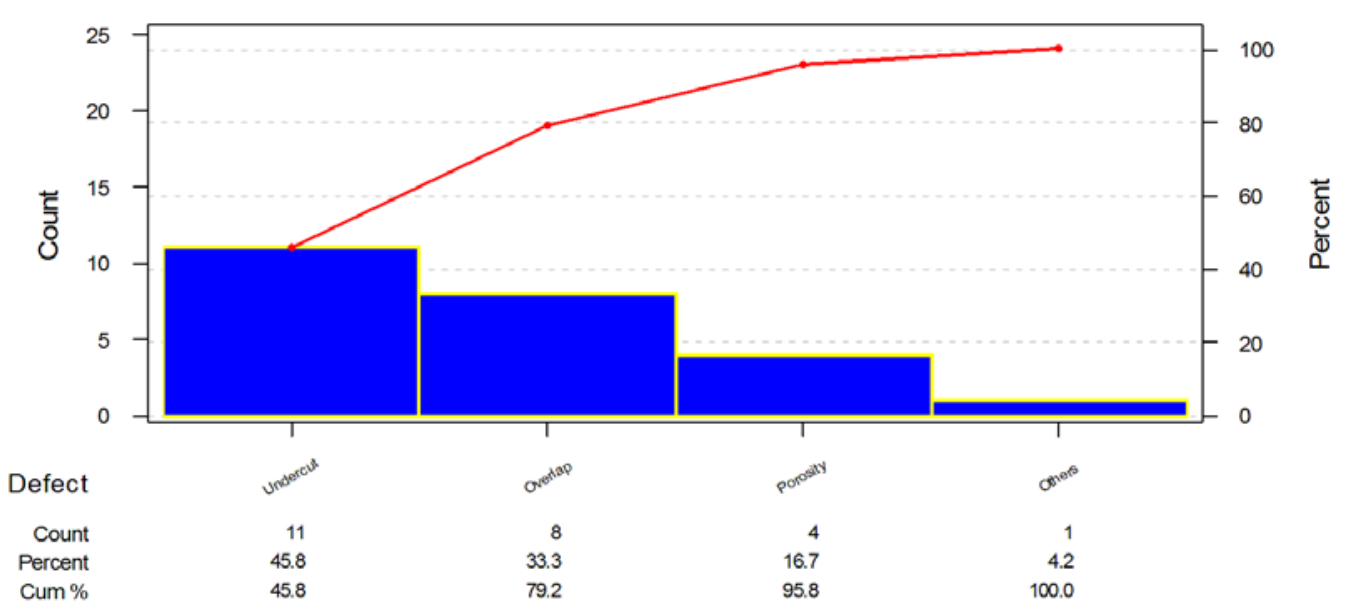

Gambar 5. Diagram Pareto Data Cacat

\section{Diagram Pareto}

Diagram pareto dibuat untuk menunjukkan jenis cacat produk dimulai dari yang terbesar sampai dengan jenis cacat yang terkecil serta jumlah cacat dan persentase kumulatif cacat produk. Diagram pareto dengan data cacat dari bulan Mei 2013 hingga September 2013 dapat dilihat pada Gambar 5.

Berdasarkan diagram pada Gambar 5 di atas, dapat diketahui bahwa kegagalan yang paling banyak pada produksi bucket adalah jenis cacat undercut yang disebabkan oleh pengelasan.

\section{Diagram Sebab Akibat}

Diagram sebab-akibat dibuat untuk mengetahui faktor-faktor yang menyebabkan terjadinya cacat undercut pada proses produksi Bucket tipe ZX 200 GP. Analisis penyebab cacat mempertimbangkan beberapa faktor, yakni: bahan (material), manusia (human), mesin (machine), metode (method), dan lingkungan (environment). Gambar 6 hingga Gambar 9 memperlihatkan diagram sebabakibat dari keempat jenis cacat.

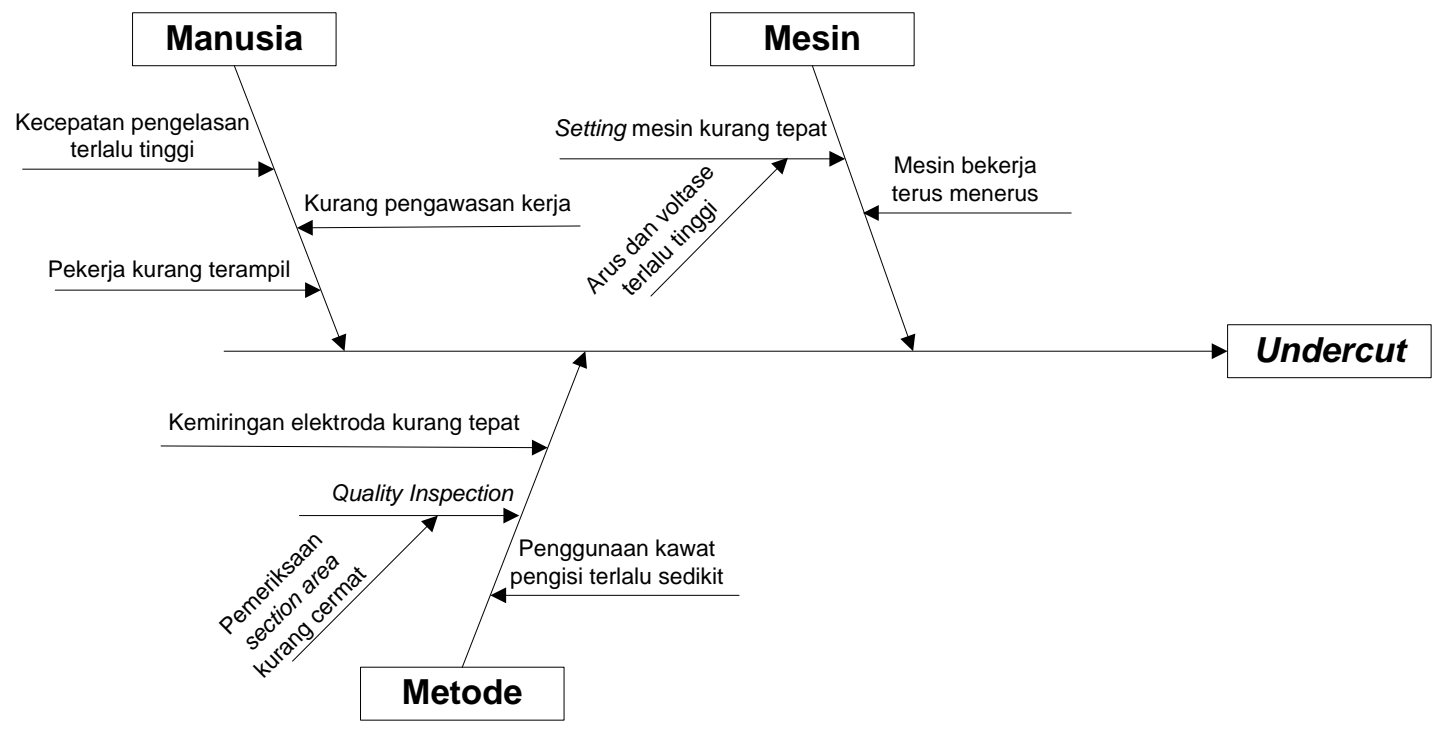

Gambar 6. Diagram Sebab Akibat Cacat Undercut 
Analisis Pengendalian Kualitas Produk Bucket TIPE ZX 200 GP Dengan Metode Statistical Process Control dan Failure Mode and Effect Analysis (Studi Kasus: PT. CDE)

Wilson Kosasih, Adianto dan Erickson

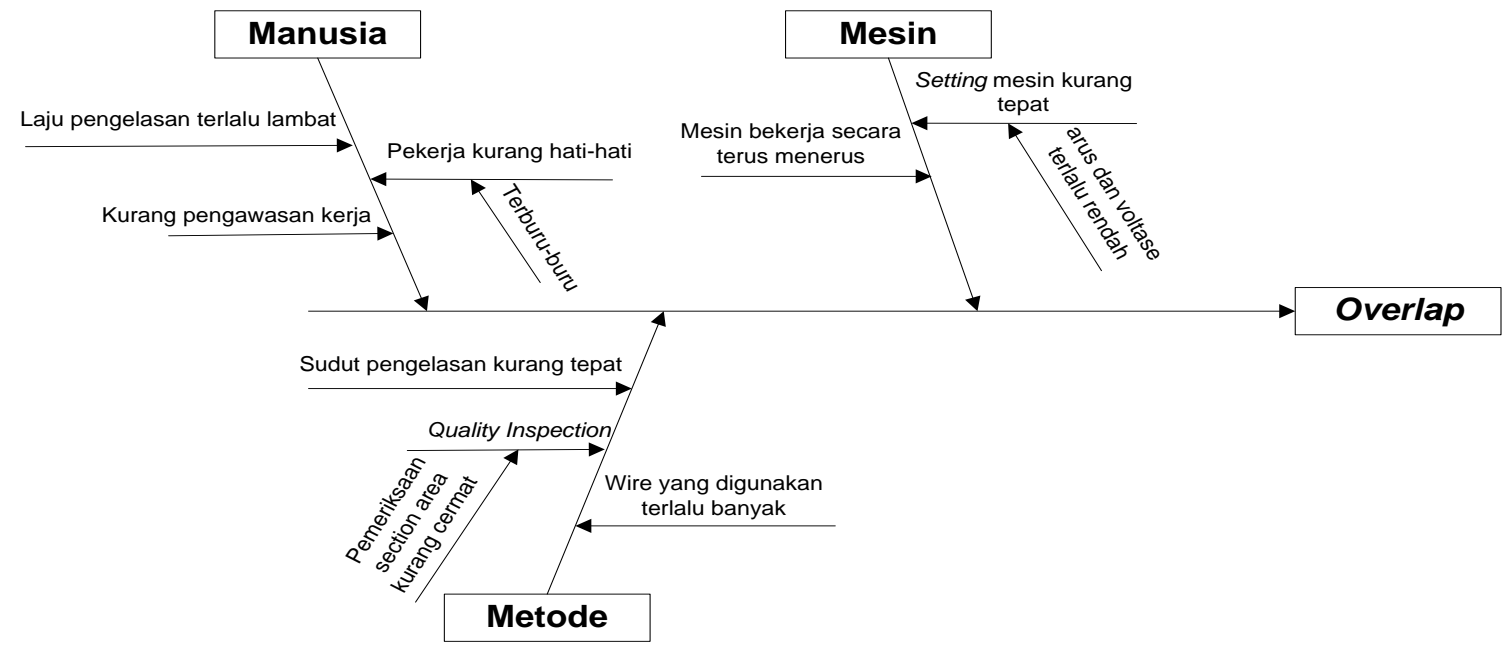

Gambar 7. Diagram Sebab Akibat Cacat Overlap

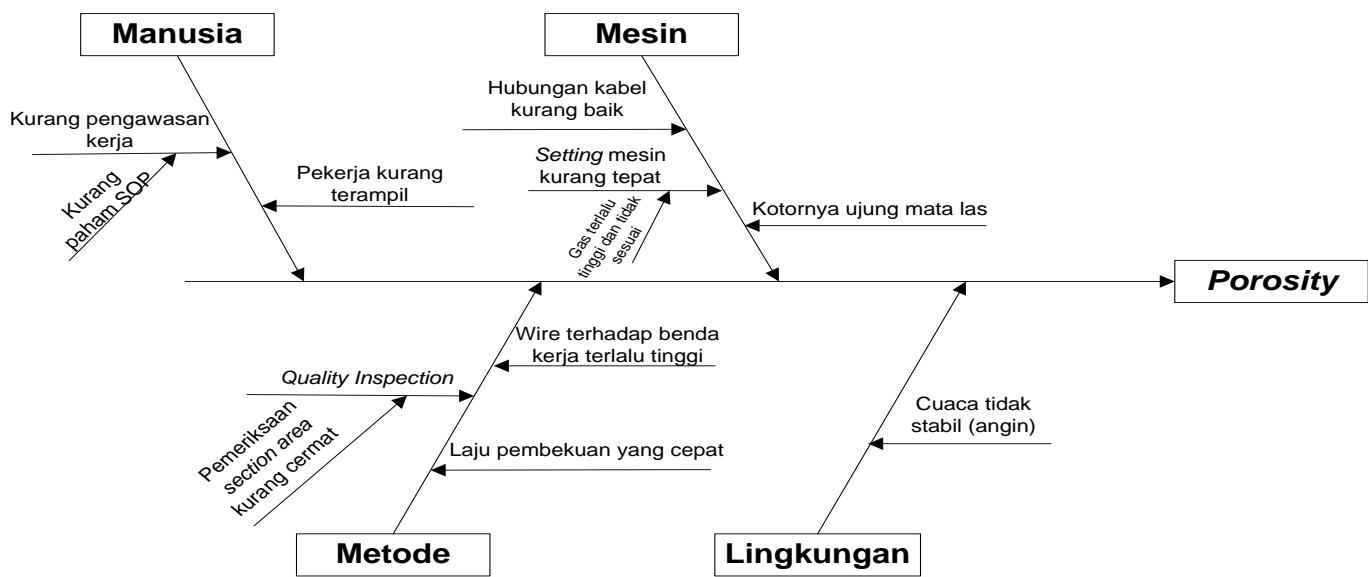

Gambar 8. Diagram Sebab Akibat Cacat Porosity

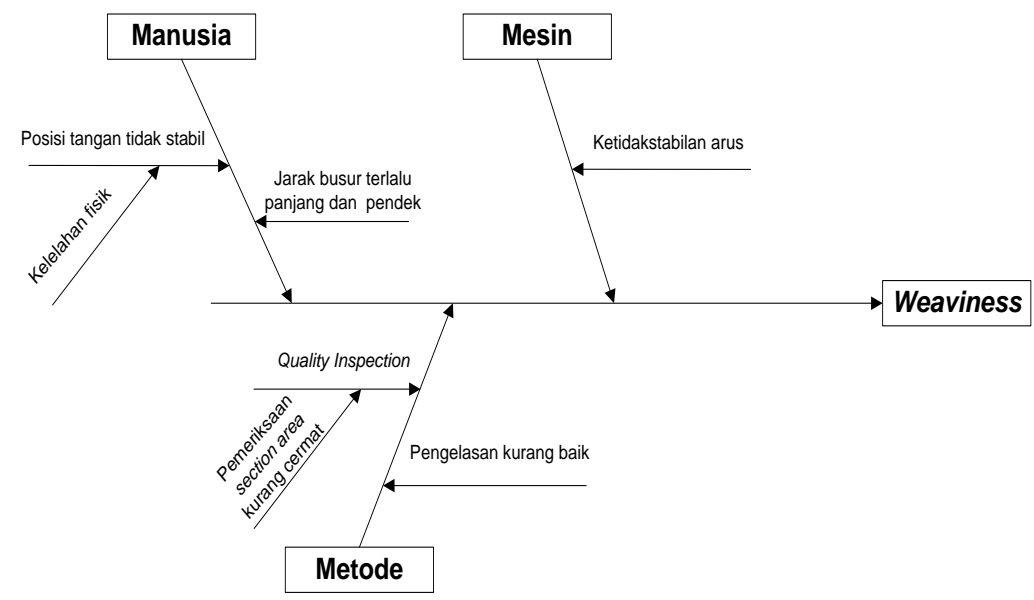

Gambar 9. Diagram Sebab Akibat Cacat Weaviness

\section{Prioritas Penanganan Permasalahan}

Penetapan nilai dari severity, occurrence, dan detectability dilakukan berdasarkan hasil wawancara dengan pihak perusahaan yang terkait di bagian produksi. Tabel detail FMEA untuk semua jenis kegagalan pada Bucket tipe ZX 200 GP dapat dilihat pada Tabel 2.

Berdasarkan hasil pemberian nilai severity, occurrence, dan detectability, maka didapatkan urutan 5 ranking tertinggi yang 
diambil dari nilai Risk Priority Number (RPN). Urutan prioritas penanganan permasalahan pada bucket tipe ZX 200 GP yang dapat dilihat pada Tabel 3.

Tabel 2. FMEA Proses Pengelasan

\begin{tabular}{|c|c|c|c|c|c|c|c|c|c|}
\hline No & $\begin{array}{l}\text { Fungsi } \\
\text { proses }\end{array}$ & $\begin{array}{c}\text { Jenis } \\
\text { Kegagalan }\end{array}$ & S & $\begin{array}{l}\text { Penyebab } \\
\text { Kegagalan }\end{array}$ & $\mathrm{O}$ & $\begin{array}{c}\text { Kontrol yang } \\
\text { dilakukan }\end{array}$ & $\mathrm{D}$ & Recommended Action & RPN \\
\hline \multirow[t]{9}{*}{1} & Pengelasan & Undercut & 7 & $\begin{array}{l}\text { Setting mesin } \\
\text { yang kurang } \\
\text { tepat }\end{array}$ & 6 & $\begin{array}{l}\text { Pemeriksaan } \\
\text { mesin las }\end{array}$ & 6 & $\begin{array}{l}\text { Setting ulang arus dan } \\
\text { tegangan }\end{array}$ & 252 \\
\hline & & & & $\begin{array}{l}\text { Kotornya ujung } \\
\text { mata las }\end{array}$ & 3 & $\begin{array}{l}\text { Pengendalian } \\
\text { mata las }\end{array}$ & 4 & $\begin{array}{l}\text { Pembersihan mata las } \\
\text { secara berkala }\end{array}$ & 84 \\
\hline & & & & $\begin{array}{l}\text { Penggunaan } \\
\text { mesin terus } \\
\text { menerus }\end{array}$ & 3 & $\begin{array}{l}\text { Penggunaan } \\
\text { mesin } \\
\text { seperlunya }\end{array}$ & 3 & $\begin{array}{l}\text { Mengendalikan waktu } \\
\text { mesin yang beroperasi }\end{array}$ & 63 \\
\hline & & & & $\begin{array}{l}\text { Penggunaan } \\
\text { kawat terlalu } \\
\text { sedikit }\end{array}$ & 5 & $\begin{array}{l}\text { Pengaturan } \\
\text { umlah kawat }\end{array}$ & 2 & $\begin{array}{l}\text { Memberikan prosedur } \\
\text { pengelasan yang jelas }\end{array}$ & 70 \\
\hline & & & & $\begin{array}{l}\text { Kurang quality } \\
\text { inspection }\end{array}$ & 5 & $\begin{array}{l}\text { Penggunaan alat } \\
\text { ukur }\end{array}$ & 5 & $\begin{array}{l}\text { Meningkatkan quality } \\
\text { inspection }\end{array}$ & 175 \\
\hline & & & & $\begin{array}{l}\text { Kemiringan } \\
\text { elektroda } \\
\text { kurang tepat }\end{array}$ & 7 & $\begin{array}{l}\text { Pengaturan } \\
\text { kemiringan } \\
\text { elektroda }\end{array}$ & 6 & $\begin{array}{l}\text { Kemiringan kawat las } \\
10^{0}\end{array}$ & 294 \\
\hline & & & & $\begin{array}{l}\text { Kecepatan } \\
\text { pengelasan } \\
\text { terlalu tinggi }\end{array}$ & 8 & $\begin{array}{l}\text { Pengaturan } \\
\text { kecepatanlas }\end{array}$ & 6 & $\begin{array}{l}\text { Mengurangi kecepatan } \\
\text { pengelasan }\end{array}$ & 336 \\
\hline & & & & $\begin{array}{l}\text { Kurang } \\
\text { pengawasan } \\
\text { kerja }\end{array}$ & 6 & $\begin{array}{l}\text { Pengarahan } \\
\text { kerja oleh } \\
\text { supervisor }\end{array}$ & 2 & $\begin{array}{l}\text { Melakukan } \\
\text { pengawasan secara } \\
\text { intensif }\end{array}$ & 84 \\
\hline & & & & $\begin{array}{l}\text { Pekerja kurang } \\
\text { terampil }\end{array}$ & 8 & $\begin{array}{l}\text { Persiapan } \\
\text { sebelum bekerja }\end{array}$ & 7 & $\begin{array}{l}\text { Pemberian latihan } \\
\text { khusus kepada pekerja }\end{array}$ & 392 \\
\hline \multirow[t]{8}{*}{2} & Pengelasan & Overlap & 5 & $\begin{array}{l}\text { Penggunaan } \\
\text { wire terlalu } \\
\text { banyak }\end{array}$ & 6 & $\begin{array}{l}\text { Pengurangan } \\
\text { jumlah kawat }\end{array}$ & 6 & $\begin{array}{l}\text { Memberikan prosedur } \\
\text { pengelasan yang tepat }\end{array}$ & 180 \\
\hline & & & & $\begin{array}{l}\text { Pekerja kurang } \\
\text { berhati-hati }\end{array}$ & 6 & $\begin{array}{l}\text { Pengarahan } \\
\text { kerja oleh } \\
\text { supervisor }\end{array}$ & 2 & $\begin{array}{l}\text { Memberikan } \\
\text { pengarahan instruksi } \\
\text { yang jelas }\end{array}$ & 60 \\
\hline & & & & $\begin{array}{l}\text { Setting mesin } \\
\text { kurang tepat }\end{array}$ & 6 & $\begin{array}{l}\text { Pemeriksaan } \\
\text { mesin las }\end{array}$ & 5 & $\begin{array}{l}\text { Setting ulang arus dan } \\
\text { tegangan }\end{array}$ & 150 \\
\hline & & & & $\begin{array}{l}\text { Pengunaan } \\
\text { mesin terus } \\
\text { menerus }\end{array}$ & 2 & $\begin{array}{l}\text { Penggunaan } \\
\text { mesin } \\
\text { seperlunya }\end{array}$ & 1 & $\begin{array}{l}\text { Mengendalikan waktu } \\
\text { mesin yang beroperasi }\end{array}$ & 10 \\
\hline & & & & $\begin{array}{l}\text { Sudut } \\
\text { pengelasan } \\
\text { kurang tepat }\end{array}$ & 8 & $\begin{array}{l}\text { Pengaturan } \\
\text { sudut } \\
\text { pengelasan }\end{array}$ & 5 & $\begin{array}{l}\text { Sudut pengelasan } \\
\text { sekitar } 70^{\circ}-80^{\circ}\end{array}$ & 200 \\
\hline & & & & $\begin{array}{l}\text { Laju pengelasan } \\
\text { kurang cepat }\end{array}$ & 7 & $\begin{array}{l}\text { Pengaturan } \\
\text { kecepatan las }\end{array}$ & 7 & $\begin{array}{l}\text { Laju pengelasan } \\
\text { dipercepat }\end{array}$ & 245 \\
\hline & & & & $\begin{array}{l}\text { Kurang } \\
\text { pengawasan } \\
\text { kerja }\end{array}$ & 4 & $\begin{array}{l}\text { Pengarahan } \\
\text { kerja oleh } \\
\text { supervisor }\end{array}$ & 2 & $\begin{array}{l}\text { Melakukan } \\
\text { pengawasan secara } \\
\text { intensif }\end{array}$ & 40 \\
\hline & & & & $\begin{array}{l}\text { Kurang quality } \\
\text { inspection }\end{array}$ & 3 & $\begin{array}{l}\text { Penggunaan alat } \\
\text { ukur }\end{array}$ & 5 & $\begin{array}{l}\text { Meningkatkan quality } \\
\text { inspection }\end{array}$ & 75 \\
\hline
\end{tabular}

Data pada Tabel 3 menunjukkan bahwa, nilai RPN didapatkan pada jenis cacat undercut yaitu pekerja yang kurang terampil, kecepatan pengelasan terlalu tinggi, kemiringan elektroda kurang tepat, setting mesin kurang tepat, dan kurangnya pemeriksaan kualitas. Akibat yang terjadi dari jenis kegagalan ini adalah keretakan pada sambungan pengelasan. Apabila tingkat keparahan semakin tinggi, maka dapat 
Analisis Pengendalian Kualitas Produk Bucket TIPE ZX 200 GP Dengan Metode Statistical Process Control dan Failure Mode and Effect Analysis (Studi Kasus: PT. CDE)

Wilson Kosasih, Adianto dan Erickson

Tabel 3. Akar Permasalahan Prioritas Utama

\begin{tabular}{cllcc}
\hline $\begin{array}{c}\text { Fungsi } \\
\text { Proses }\end{array}$ & $\begin{array}{c}\text { Jenis } \\
\text { Kegagalan }\end{array}$ & \multicolumn{1}{c}{ Akar Permasalahan } & RPN & \multirow{2}{*}{ Ranking } \\
\hline \multirow{4}{*}{ Pengelasan } & & 1. Pekerja kurang terampil & 392 & 1 \\
& \multirow{2}{*}{ Undercut } & 2. Kecepatan pengelasan terlalu tinggi & 336 & 2 \\
& & 3. Kemiringan elektroda kurang tepat & 294 & 3 \\
& & 4. Setting mesin yang kurang tepat & 252 & 4 \\
& 5. Kurang quality inspection & 175 & 5 \\
\hline
\end{tabular}

Tabel 4. Action Plan untuk Cacat Undercut

\begin{tabular}{|c|c|c|}
\hline $\begin{array}{c}\text { Jenis } \\
\text { Kegagalan }\end{array}$ & Akar Permasalahan & Action Plan \\
\hline \multirow{5}{*}{ Undercut } & 1. Pekerja kurang terampil & Mempekerjakan welder yang telah bersertifikasi \\
\hline & 2. Kecepatan pengelasan terlalu tinggi & $\begin{array}{l}\text { Mengurangi kecepatan pengelasan sesuai dengan } \\
\text { ketebalan material }\end{array}$ \\
\hline & 3. Kemiringan elektroda kurang tepat & $\begin{array}{l}\text { Melakukan pengarahan mengenai kemiringan } \\
\text { elektroda yang sesuai dengan posisi pengelasan. }\end{array}$ \\
\hline & 4. Setting mesin yang kurang tepat & $\begin{array}{l}\text { Mengatur besar arus dan tegangan pengelasan sesuai } \\
\text { dengan tebal bahan dan diameter kawat elektroda. }\end{array}$ \\
\hline & 5. Kurang quality inspection & $\begin{array}{l}\text { Melakukan pemeriksaan kualitas secara rutin dan } \\
\text { segera melakukan tindakan perbaikan bila terjadi } \\
\text { kegagalan saat produksi. }\end{array}$ \\
\hline
\end{tabular}

menyebabkan patahan pada bagian sambungan top box ke hook up.

\section{Action Plan}

Setelah ditentukan jenis kegagalan yang menjadi prioritas penanganan masalah, maka dilakukan pemberian usulan perbaikan untuk menangani permasalahan yang terdapat pada jenis kegagalan ini. Rencana/tindakan perbaikan untuk cacat undercut dapat dilihat pada Tabel 4.

Mengenai kekurang-trampilan dari para pekerja, diberikan usulan tindakan perbaikan untuk mengurangi terjadinya jenis kegagalan cacat undercut adalah mempekerjakan pekerja atau welder yang telah bersertifikasi. Dalam hal ini yang dimaksud dengan sertifikasi adalah pekerja harus memiliki teknik pengelasan yang baik, mengetahui standar pengelasan, cacat las, dan memiliki pengetahuan keselamatan kerja. Dengan mempekerjakan pekerja yang telah bersertifikasi dengan baik, maka produk yang dihasilkan dapat memiliki kualitas yang baik.

Permasalahan kedua disebabkan oleh kecepatan pengelasan yang terlalu tinggi. Kecepatan pengelasan yang tinggi ini disebabkan oleh kurangnya pemahaman pekerja mengenai prosedur pengelasan yang tepat [3]. Kecepatan pengelasan yang dilakukan pada top box joint to hook up yaitu $310 \mathrm{~mm} /$ menit dengan ketebalan plat $12 \mathrm{~mm}$. Rencana tindakan perbaikan yang diberikan untuk mengurangi terjadinya jenis kegagalan ini adalah mengurangi kecepatan pengelasan sesuai dengan ketebalan plat. Dengan meningkatnya ketebalan plat, maka kecepatan pengelasan harus diturunkan. Standar kecepatan pengelasan pada bucket dapat dilihat pada Tabel 5.

Tabel 5. Standar Kecepatan Pengelasan pada

\begin{tabular}{cc} 
Bucket & \\
\hline $\begin{array}{c}\text { Tebal Plat } \\
(\mathrm{mm})\end{array}$ & $\begin{array}{c}\text { Kecepatan Pengelasan } \\
(\mathrm{mm} / \text { menit })\end{array}$ \\
\hline 12 & 270 \\
25 & 210 \\
\hline
\end{tabular}

(sumber: diolah dari hasil FDG - focus discussion group - dengan pihak manajemen)

Permasalahan Ketiga disebabkan oleh kemiringan elektroda yang kurang tepat. Kemiringan elektroda ini disebabkan oleh kesalahan posisi kerja saat pengelasan. Kemiringan elektroda dalam melakukan pengelasan adalah $5^{\circ}$ terhadap garis vertikal. Tindakan perbaikan yang diberikan untuk mengurangi terjadinya jenis kegagalan ini adalah Melakukan pengarahan mengenai kemiringan elektroda yang sesuai dengan posisi pengelasan. Posisi pengelasan yang digunakan dalam pengelasan bucket yaitu posisi mendatar 
atau horizontal, dimana kedudukan benda kerja dibuat tegak dan arah elektroda mengarah horizontal. Sewaktu pengelasan berlangsung, elektroda dibuat miring $10^{\circ}$ terhadap garis vertikal dan sekitar $70^{\circ}-80^{\circ}$ ke arah benda kerja.

Permasalahan keempat disebabkan oleh arus dan tegangan yang digunakan terlalu tinggi. Hal ini dapat menyebabkan hasil pengelasan yang kurang baik pada bucket. Arus yang digunakan dalam memproduksi bucket yaitu 360 Ampere. Sedangkan, tegangan yang digunakan pada diameter kawat $1,2 \mathrm{~mm}$ yaitu 36 Volt. Rencana tindakan perbaikan yang diberikan untuk mengurangi terjadinya jenis kegagalan ini adalah mengatur besar arus dan tegangan sesuai dengan ketebalan plat dan diameter kawat las. Standar parameter arus dan tegangan pada pengelasan bucket dapat dilihat pada Tabel 6.

Tabel 6. Standar Parameter Arus dan Tegangan pada Pengelasan Bucket

\begin{tabular}{cccc}
\hline $\begin{array}{c}\text { Diameter } \\
\text { kawat }\end{array}$ & $\begin{array}{c}\text { Arus } \\
(\mathrm{A})\end{array}$ & $\begin{array}{c}\text { Tegangan } \\
(\mathrm{V})\end{array}$ & $\begin{array}{c}\text { Tebal } \\
(\mathrm{mm})\end{array}$ \\
\hline 0,8 & $60-150$ & $14-22$ & $0,8-2,0$ \\
0,9 & $150-220$ & $22-25$ & $2,0-10$ \\
1,0 & $220-290$ & $25-29$ & $10-18$ \\
1,2 & $290-350$ & $29-32$ & $18-25$ \\
\hline \multicolumn{4}{c}{ (sumber: diolah dari hasil FDG dengan pihak } \\
\multicolumn{4}{c}{ manajemen) }
\end{tabular}

Rencana tindakan perbaikan yang diberikan untuk mengurangi faktor penyebab kurangnya pemeriksaan kualitas adalah melakukan pemeriksaan kualitas secara rutin dengan menggunakan alat ukur pemeriksaan yang sesuai dan segera dilakukan tindakan bila terjadi kegagalan produk. Pemeriksaan kualitas secara rutin bertujuan agar tidak terjadi kelolosan pada produk yang mengalami kegagalan produksi.

\section{KESIMPULAN}

Berdasarkan data produksi bucket tipe ZX 200 GP pada bulan Mei 2013 hingga September 2013 dapat diketahui bahwa jenis cacat undercut pada bagian top box joint to hook up merupakan jenis cacat yang paling dominan mengalami kegagalan produksi. Akar permasalahan yang menjadi penyebab munculnya kegagalan pada jenis cacat undercut adalah setting mesin yang kurang tepat, kotornya ujung mata las, penggunaan mesin secara terus menerus, pemakaian kawat terlalu sedikit, kurang pemeriksaan kualitas, kemiringan elektroda yang kurang tepat, kecepatan pengelasan terlalu tinggi, kurang pengawasan kerja, dan pekerja yang kurang terampil. Dari hasil analisis menggunakan FMEA proses, didapatakan akar permasalahan dengan tingkat prioritas tertinggi untuk jenis cacat undercut yaitu pekerja yang kurang terampil/kompeten (dengan nilai RPN sebesar 392) yang dapat mengakibatkan terjadinya keretakan pada sambungan pengelasan. Terdapat beberapa usulan/tindakan perbaikan yang diberikan kepada pihak manajemen perusahaan, antara lain: mempekerjakan pekerja atau welder yang telah bersertifikasi, mengurangi kecepatan pengelasan sesuai dengan ketebalan material, melakukan pengarahan mengenai kemiringan elektroda yang sesuai dengan posisi pengelasan, mengatur besar arus dan tegangan pengelasan sesuai dengan tebal bahan dan diameter kawat elektroda, melakukan pemeriksaan kualitas secara rutin dan segera melakukan tindakan perbaikan bila terjadi kegagalan saat produksi.

\section{DAFTAR PUSTAKA}

[1]. Ariani, Dorothea Wahyu., 1999, Manajemen Kualitas, Universitas Atma Jaya, Yogyakarta.

[2]. Ishikawa, Kaoru, 1989, Teknik Penuntun Pengendalian Mutu, Mediyatama Sarana Perkasa, Jakarta.

[3]. Sonawan, Hery dan Rochim Suratman, 2004, Pengantar untuk Memahami Proses Pengelasan Logam, Cetakan 1, Alfabeta, Bandung.

[4]. Stamatis, D.H., 1995,Failure Mode and Effect Analysis: FMEA from Theory to Execution, ASQC. 